city", it would be well advised to assemble an international commission composed of 20 members to be drawn equally from the four following groups: (1) science leaders in India, (2) prominent Indian expatriate scientists in the United States, (3) leaders of scientific establishments in Europe, and (4) science educators and researchers in the United States. The task should be to make proposals which will improve science education in Indian universities, enhance the research environment in the universities and institutes, and develop support facilities such as manufacturing and servicing state-of-the-art instrumentation. I am sure that scientists from the United States and Europe would be glad to participate in a summer "sabbatical" of this type in the interest of world science.

S. SUBRAMANIAN

Miles Laboratories Inc.,

Elkhart, Indiana 46515, USA

SIR - Although we feel that there is nothing wrong in India's plans to build a technology city (Nature 305, 350; 1983) similar to the Tsukuba science city in Japan, we believe that this would not solve the main problem - India should stop deliberately encouraging its experts to leave the country. We agree with the suggestion (Nature 306, 310; 1983) that in order to encourage intellectuals to remain in India, money must be spent on improving the existing facilities for research. In addition, we suggest that India should make further provisions to send its young and talented scientific staff abroad for advanced training, and provide them with suitable facilities on their return. We understand that many scientists who go abroad are forced to resign their positions at home because of stringent governmental policies. When better conditions for research are available to the many intellectuals who remain in the country, India can stop recalling experts from abroad.

P. BALAKRISHNA MURTHY

Research Institute for Nuclear

Medicine and Biology,

Hiroshima University,

RAMSUNDAR RAM KANAUJIA

Department of Orthopaedic Surgery,

School of Medicine.

Hiroshima University,

1-2-3 Kasumi-cho, Hiroshima 734, Japan

\section{Submarines risky?}

SIR - The proposal to restrict nuclear arsenals to the seas where they can carry out their stated function of deterrence (Nature 23 February, p.680) has much to commend it, but certainly needs additions to cover antisubmarine warfare. Research in this field would have to be prohibited and those systems already established be dismantled, as they threaten to destroy the very invulnerability of submarines on which the whole proposal is based.

47 Conduit Road,

ROBERTWALL

Bedford MK40 IEQ, UK

\section{PWR in haste}

SIR - In his article, "Next reactor still not decided" (Nature 26 January, p.307), your correspondent states that the Central Electricity Generating Board plans to build a pressurized water reactor (PWR) at Sizewell in "a record 19 months".

Would that such miracles could happen. Clearly his figure is a misquote for the 90 months from laying main foundations that CEGB is estimating for investment appraisal purposes for the construction of Sizewell B.

However, this still would not be a record. Our Magnox nuclear stations were in commercial operation in a shorter period, and some US PWRs and may French ones have been built in less than 90 months. Indeed, CEGB also has set itself a construction target of less than 90 months.

The article concludes with a misleadingly pessimistic picture of developments in the project. General inflation has, of course, resulted in costs rising in market price terms. But, so far, there has been no increase in our total estimate of the cost of Sizewell B in real terms (that is, at March 1982 price levels).

Although the length of the public inquiry means that we cannot place main foundations in line with the original timetable, this does not affect the 90 -month construction period. It does, however, mean that the electricity consumer will have to wait longer for the economic benefits CEGB believes that Sizewell B, if approved, would bring.

\section{Economic Adviser,}

P. E. WATTS

Sizewell 'B' Public Inquiry

Central Electricity Generating Board,

PO Box 333, The Maltings,

Snape, Suffolk IPI7 ISP, UK

\section{Not so simple}

SIR - In your issue of 1 December (Nature 306,$418 ; 1983$ ) you reproduced a year-byyear plot of Norwegian tobacco consumption for 1950-1980, presumably intended to support the argument that a ban on cigarette advertising can be effective in limiting the growth of consumption. The graph seems to be open to question on two grounds. One is that the rising trend changes to a decline before the year (1975) when the act banning cigarette advertising came into force. The other is the implication that the almost linear increase in consumption between 1950 and 1970 was caused by advertising. It would be prudent here to investigate the role of obvious economic variables such as prices and incomes. I have no data on tobacco prices in Norway, but a rough replotting of per capita tobacco consumption against per capita income at constant prices shows that the ratio between them had been declining since 1950 , and against this background the further decline since 1970 looks much less striking. Such questions should be investi- gated by standard econometric techniques before policy conclusions are drawn from prima facie correlations. The case for discouraging tobacco consumption on health grounds can only be weakened by opportunistic use of incomplete statistics.

Evaluation and Planning Centre,

G. E. CUMPER

London School of Hygiene and

Tropical Medicine,

Gower St, London WCI, UK

\section{Paid referees}

SIR - A recent letter (Nature 2 February, p.408) drew attention to page charges in journals and suggested a possible credit system for referees. However, according to an advertising circular recently received by me, at least one new journal (Engineering Computations) is adopting a "rigorous, remunerated reviewing policy". Apparent$l y$, this is in the hope that payment to referees will minimize the time taken to review the manuscript, thus ensuring rapid publication. I feel that this is a false premise on two counts. First, an examination of the received, revised and publication dates of many papers reveals that the delay between acceptance of a manuscript and publication is often longer than the time between submission and acceptance, which includes the time taken by the author to revise the manuscript. Second, journals, including Nature, achieve rapid publication without resort to payment of referees.

The adoption of remunerated reviewing policy by any journal can only be a retrograde step which may be interpreted by some people as further evidence of scientific integrity being sacrificed by financial gain. Also, it can only further increase the financial load imposed on individual scientists and libraries. Let us hope that the day never comes when a person can state his or her occupation as "professional journal referee'!

\section{Department of Applied Mathematics \\ and Theoretical Physics, \\ University of Cambridge, \\ Silver Street, Cambridge CB3 9EW, UK}

\section{Laughing matter}

SIR - I am compiling an anthology, "Science with a Smile", and should welcome contributions of humour in the sciences: physics, chemistry, astronomy, mathematics, earth sciences, life sciences, and computer science - historic and contemporary. Appropriate would be anecdotes, biographical notes, cartoons, parodies, verse, examples of self-deception and hoaxes. I especially seek pieces which, while humorous, also have value in the history of science, providing insight into changing attitudes and personalities.

ROBERT L. WEBER

104 Davey Laboratory,

University Park,

Pennsylvania 16802, USA 